\section{Gorilla Skulls in the Bristol Museum}

IN the course of rearrangement of the study collections in the Department of Zoology, it has recently been discovered that the Bristol Museum and Art Gallery possesses the three gorilla skulls (Reg. Nos. Ab 1993, 1994, 1995) from which Prof. (afterwards Sir Richard) Owen first described this animal to the Zoological Society of London in a paper read on February 22, 1848. This was published in Trans. Zool. Soc., 3, pp. 381-422 (1849) and Plates LVIIILXIII as "Osteological Contributions to the Natural History of the Chimpanzees (Troglodytes, Geoffroy) including the description of the skull of a large species (Troglodytes Gorilla, Savage) discovered by Thomas S. Savage M.D. in the Gaboon Country, West Africa". One of the skulls (Ab 1993) is figured in Plates LXI-LXIII and, as related on p. 391, they were procured in December 1847.

In a later paper by the same author in Trans. Zool. Soc., 4, pp. 75-77 (1862), a detailed description is given of another skull ( $\mathrm{Ab}$ 1996), and it is figured in Plates XXVI-XXVIII. The bisection of the skull was carried out under Prof. Owen's direction as mentioned on p. 77 .

Casts of these four skulls were presented to the Museum of the Royal College of Surgeons in 1848, and appear as Nos. 5180-5183 in "Descriptive Catalogue of the Osteological Series. Vol. II. Mammalia Placentalia" (1853) where, on pp. 803-805, there are descriptions, including a further detailed one of $\mathrm{Ab} 1996$.

Some more notes are given on p. 9 of a later "Catalogue of Specimens illustrating Osteology and Dentition of Vertebrated Animals, Part II. Mammalia other than Man" (1884) by W. H. Flower and J. G. Garson.

In addition to the above, there are in the collections another skull of a male presented at the same time (1848) as Ab 1996, and a mounted adult male and its skeleton received in 1865 .

Details of these specimens are as follows :

(1) Skull of adult male, without mandible, procured by Capt. George Wagstaffe at the Gaboon River, West Africa, in December 1847. Brought to England by Capt. Wagstaffe, ship Jno. Cabot. Donor : Mr. S. Stutchbury, August 3, 1848. Reg. No. : Ab 1993.

(2) Skull of mature male, without mandible, same history and donor as No. 1. Reg. No. : Ab 1994.

(3) Skull of adult female, without mandible, same history and donor as Nos. 1 and 2. The top of the cranium has been divided from the rest of the skull. Reg. No. : Ab 1995.

(4) Skull of adult male without mandible, from River Danger (=Muni River), West Africa. Donor : Capt. Harris, ship Englishman, August 3, 1848. (This skull was bisected vertically and longitudinally later.) Reg. No.: Ab 1996.

(5) Skull of male, without mandible, from River Danger, West Africa. Donor : Mr. Townsend, ship Englishman, August 3, 1848. Reg. No. : Ab 1997.

(6) Mounted specimen of adult male from Gaboon River, West Africa. Donor : Mr. A. Gordon, of Gaboon, December 30, 1865. Reg. No.: A 4890.

(7) Complete skeleton of No. 6. The height of the animal was $5 \mathrm{ft} .5$ in. Reg. No. : A 4837.

Bristol Museum and

H. TetLey.

Art Gallery.

Oet. 3.

\section{Ring Deposits on Glass by Positive Ray Bombard- ment}

Positrve rays of hydrogen were passed through a hole of $2 \mathrm{~mm}$. diameter and $6 \mathrm{~mm}$. long in the centre of a cathode of brass faced with an aluminium plate. A glass window kept perpendicular to the beam, eleven centimetres behind the front face of the cathode, showed formations of deposits with welldefined rings after the tube was worked at different cathode falls corresponding to a maximum of 25,000 volts D.c., current $1.7 \mathrm{~m}$. amp. The total time of exposure was about twenty-five hours. On examination by transmitted light of the place where the rays fell directly, it was found to be transparent. The rings were brown. The first ring is sharp and circular, with a thickness of $0.5 \mathrm{~mm}$. and a diameter of $8 \mathrm{~mm}$. The second ring is also quite circular, of the same thickness as the first, but not quite concentric with it. The diameter of this ring is about $16 \mathrm{~mm}$. only; two-fifths of the third ring is visible, the diameter is $24-30 \mathrm{~mm}$., but it is nearly concentric with the second ring.

The deposits have been observed by previous workers, but not the rings. Von H. Raether ${ }^{1}$ examined similar deposits by electron diffraction, and concluded that they must be due to carbon formed from the decomposition of the hydrocarbons present in the discharge tube and produced from grease or at wax joints. The rings cannot be due to interference. The phenomenon presents many interesting features as a closer extended study with excellent photographic results has revealed, and will be reported in detail elsewhere.

$\begin{array}{cl}\text { Physical Laboratory, } & \text { B. DASANNACHARYA. } \\ \text { Hindu University, } & \text { L. T. CH. SAPLONKAR. } \\ \text { Benares. } & \\ \text { Aug. 25. } & \end{array}$

${ }^{1}$ Phys. Z., 34, 492 ; 1933.

\section{Spectra of $\mathrm{SeO}$ and $\mathrm{SeO}_{2}$}

IN continuation of earlier work ${ }^{1}$ on $\mathrm{SO}_{2}$, the emission bands of $\mathrm{SeO}$ and the absorption bands of $\mathrm{SeO}_{2}$ have been analysed. The former consist of a long $v^{\prime}=0$ progression and a short $v^{\prime}=1$ progression. The origin of the system cannot be definitely located but the $v^{\prime}=0$ progression can be expressed by the following formula

$$
\nu=30433-\left(882 v^{\prime \prime}-6 v^{\prime \prime 2}\right) \text {. }
$$

Considerations of intensity distribution lead us to $33167 \mathrm{~cm}^{-1}$ as $\nu_{0}$ and $\omega^{\prime \prime}=910 \mathrm{~cm} .^{-1}$, and the energy of dissociation of unexcited $\mathrm{SeO}$ will therefore be $4 \cdot 17$ volts. The vibrational frequency of the excited state $\omega^{\prime}$ is $513 \mathrm{~cm}^{-1}$

The analysis of the spectrum of $\mathrm{SeO}_{2}$ indicates two modes of vibration $\omega_{2}$ and $\omega_{3}$ both in the ground and in the excited state, the deforming vibration $\omega_{1}$ being absent. The frequencies of the symmetric valence vibration are $\omega_{2}^{\prime \prime}=901$ and $\omega_{2}^{\prime}=663 \mathrm{~cm} .^{-1}$; those of the antisymmetric valence vibration are $\omega_{3}^{\prime \prime}=1189$ and $\omega_{3}^{\prime}=790 \mathrm{~cm}^{-1}$. The origin of the system lies at $32560 \mathrm{~cm}^{-1}$.

The theoretical selection rule for $\Delta v_{\text {antisym. of }}$ Herzberg and Teller ${ }^{2}$ is found to be completely valid.

The close correspondence of the two energies of excitation, $\omega^{\prime \prime}$ and $\omega^{\prime \prime}, \omega^{\prime}$ and $\omega_{2}^{\prime \prime}$ of $\mathrm{SeO}$ and $\mathrm{SeO}_{2}$ respectively, indicate strong localisation of the bonds. 